\title{
Mesoporous activated carbon yielded from pre-leached cassava peels
}

\author{
R. Kayiwa* (D, H. Kasedde, M. Lubwama and J. B. Kirabira
}

\begin{abstract}
The search for alternatives to fossil-based commercial activated carbon (AC) continues to reveal new eco-friendly potential precursors, among which is agricultural waste. The key research aspect in all these endeavors is empirical ascertainment of the core properties of the resultant AC to suit a particular purpose. These properties include: yield, surface area, pore volume, and the active surface groups. It is therefore pertinent to have process conditions controlled and tailored towards these properties for the required resultant AC. Pre-leaching cassava peels with $\mathrm{NaOH}$ followed by $\mathrm{KOH}$ activation and carbonization at holding temperatures $\left(780^{\circ} \mathrm{C}\right)$ above the melting point of $\mathrm{K}\left(760^{\circ} \mathrm{C}\right)$ yielded mesoporous activated carbon with the highest surface area ever reported for cassava peel-based AC. The carbonization temperatures were between 480 and $780^{\circ} \mathrm{C}$ in an activation-carbonization stepwise process using $\mathrm{KOH}$ as the activator at a $\mathrm{KOH}$ :peel ratio of 5:2 (mass basis). A 42\% maximum yield of AC was realized along with a total pore volume of $0.756 \mathrm{~cm}^{3} \mathrm{~g}^{-1}$ and BET surface area of $1684 \mathrm{~m}^{2} \mathrm{~g}^{-1}$. The AC was dominantly microporous for carbonization temperatures below $780^{\circ} \mathrm{C}$, but a remarkable increase in mesopore volume $\left(0.471 \mathrm{~cm}^{3} \mathrm{~g}^{-1}\right)$ relative to the micropore volume $\left(0.281 \mathrm{~cm}^{3} \mathrm{~g}^{-1}\right)$ was observed at $780^{\circ} \mathrm{C}$. The Fourier transform infrared (FTIR) spectroscopy for the pre-treated cassava peels showed distortion in the $\mathrm{C}-\mathrm{H}$ bonding depicting possible elaboration of more lignin from cellulose disruption by $\mathrm{NaOH}$. A carboxylate stretch was also observed owing to the reaction of $\mathrm{Na}^{+}$ions with the carboxyl group in the raw peels. FTIR showed possible absorption bands for the AC between 1425 and $1712 \mathrm{~cm}^{-1}$ wave numbers. Besides the botanical qualities of the cassava peel genotype used, pre-leaching the peels and also increasing holding activation temperature above the boiling point of potassium enabled the modified process of producing highly porous AC from cassava peel. The scanning electron microscope (SEM) and transmission electron microscope (TEM) imaging showed well-developed hexagonal pores in the resultant $A C$ and intercalated $\mathrm{K}$ profile in the carbon matrices, respectively.
\end{abstract}

Keywords: Activated carbon, Cassava peel, Pre-leaching, FTIR, Surface area and pore volume

\section{Introduction}

Activated carbon (AC) continues to find application in both domestic and industrial processes predominantly in adsorption. However, the activated carbons available on market are very costly. Besides the off-shelf cost, the nonrenewable raw materials from which they are produced threaten the environment hence limiting their applications. With the global need to mitigate climate change

\footnotetext{
*Correspondence: ronald.kayiwa@mak.ac.ug

Department of Mechanical Engineering, College of Engineering, Design,

Art and Technology, Makerere University, P.O. Box 7062, Kampala, Uganda
}

and its eco-destructive effects, there is a need to produce AC from biomass rather than fossil sources (Yahya et al. 2015). Appreciably, research into alternative eco-friendly $\mathrm{AC}$ precursors has been immensely undertaken globally. Mainly, the clear-cut determinants for AC precursor choices are; availability, ease of handling, ease and cost of production, by-products' compositions, and intended application of the AC (Bhatnagar et al. 2015). In recent years, there has been a growing interest to produce ACs from lignocellulosic agricultural residues (Yahya et al. 2015). This is majorly attributed to their availability at a low cost, their high carbon content, and low inorganics. 
Inextricably, besides the general considerations for an $\mathrm{AC}$ precursor, the choice of a particular lignocellulosic residue for $\mathrm{AC}$ production depends on its chemical and physical properties (Menya et al. 2018). These include; moisture content, volatile matter, carbon composition, ash content, and dry matter content. Inherently, the resultant quality of the produced $\mathrm{AC}$ from a lignocellulosic precursor depends on the reactions and interactions of the different components of the precursor, mainly cellulose, hemicellulose, and lignin (Gani and Naruse 2007).

Cassava peel is one of the prospective precursors for $A C$ production. Leveraging the properties of cassava peels for $\mathrm{AC}$ is of economic importance given the few competitive applications like animal feed (Adekunle et al. 2016; Santos et al. 2015) and, potential energy production (Okudoh et al. 2014). Like other lignocellulosic biomass, for cassava peel to be harnessed for AC production, it requires pre-treatment to counteract its recalcitrance nature towards thermochemical processing. Fairly, research into harnessing cassava peel for AC production has been conducted (Parvathi et al. 2018; Salahudeen et al. 2014; Sudaryanto et al. 2006). Of note, is the microporous structure of all the resultant ACs from these studies besides the surface area at $<1600 \mathrm{~m}^{2} \mathrm{~g}^{-1}$. However, like with other lignocellulosic precursors, there is a need to enhance the core properties of activated carbons while not compromising the production process efficiency and environmental conservation standards. Moreover, the pore size distribution of the resulting activated carbon depends on the precursor, degree of initial impregnation of the catalyst used (Daud and Ali 2004; Kwiatkowski and Broniek 2017; Laine and Yunes 1992; Li et al. 2008; Liu et al. 2015).

More often in the application of ACs, the pore volume and surface area are considered the key characteristics that define the suitability of activated carbon. In practice, some processes involving $\mathrm{AC}$ utilization require higher volumes of mesopores than micropores in a given AC. Such processes include but are not limited to: adsorption of large adsorbate molecules from solutions (Alves et al. 2018), biomedical engineering, and electrochemical applications (Ibeh et al. 2019; Lu et al. 2017). Moreover, mesopores are needed for access of the micropores in processes that primarily require microporous carbons (Rodríguez-Reinoso 2006). Inextricably the active surface groups of the carbon are crucial in its application properties. Therefore, more research endeavors have been put into the surface chemistry of ACs. Hence, any attempts to enhance the porosity and surface area of a prospective $\mathrm{AC}$ from a precursor inextricably affect the surface groups too. In our past work, peels of six predominant cassava varieties in Uganda were found viable for AC production with varietal preferences accruing to the end use of the prospective AC (Kayiwa et al. 2021). NAROCAS 1 variety was the most suitable $A C$ precursor owing to its highest and lowest lignin and ash contents, respectively. Moreover, alkaline pretreatment of the same showed an increment in the lignin content hence an implied high char yield. Besides, NAROCAS 1 has been reported as one of the cassava varieties in Uganda that are resistant to common viral cassava diseases (Mukiibi et al. 2019; Shirima et al. 2020). This gives hope for the sustainability of AC production owing to an assured yield of enough cassava. Prospectively there was a need to study the produced $\mathrm{AC}$ from the variety to understand further the effect pre-leaching and a higher holding carbonization temperature have on the resultant $\mathrm{AC}$ porosity, surface area, and active surface groups. Besides, in AC processing reactions and activation mechanisms are variable depending not only on the activation parameters, but also on the reactivity of various carbon sources.

This study aimed at producing high surface area mesoporous activated carbon through pre-leaching and carbonizing at temperatures above that of the boiling point of the activating reagent base metal.

\section{Materials and methods}

\section{Preparation of activated carbon}

Activated carbon was prepared from dry peels of NAROCAS 1 cassava genotype pre-leached using $\mathrm{NaOH}$ solution. This genotype was chosen for the study due to its robust characteristics including char yield, carbon content, bulk density, and high lignin content. The proximate and ultimate characteristics of the cassava peel genotype are reported in our earlier work (Kayiwa et al. 2021). The peels were washed with distilled water to a debris-free level by gravitational flow method. They were dried in an oven at $40{ }^{\circ} \mathrm{C}$ for $12 \mathrm{~h}$ to reduce the moisture content to 10-12 (\%wt dry basis) and about $100 \mathrm{~g}$ of the dry peels was pulverized to $0.25 \mathrm{~mm}$ average particle size. $20 \mathrm{~g}$ of the pulverized peels was soaked in $150 \mathrm{ml}$ of $4.0 \% \mathrm{w} / \mathrm{v}$ $\mathrm{NaOH}$. This was followed by mixing and heating at $400 \mathrm{rpm}$ and $50{ }^{\circ} \mathrm{C}$, respectively, in a centrifuge shakerHERMLE Z326K, Germany for $3 \mathrm{~h}$, and allowing the samples to stand for $12 \mathrm{~h}$. The $\mathrm{NaOH}$-pretreated cassava peel sample was then transferred to a chromatographic column, with a filter at its bottom and rinsed with distilled water until a neutral $\mathrm{pH}$ was obtained, followed by oven drying of the sample at $105{ }^{\circ} \mathrm{C}$ for $12 \mathrm{~h} .10 \mathrm{~g}$ portions of pre-leached powdered cassava peel $(0.25 \mathrm{~mm}$ average particle size) were mixed with $\mathrm{KOH}$ at $\mathrm{KOH}$ :peel ratios of 5:2 (mass basis) and heated at $60{ }^{\circ} \mathrm{C}$ for $2 \mathrm{~h}$. The resultant slurry was dried at $100^{\circ} \mathrm{C}$ for $24 \mathrm{~h}$ and then carbonized at temperatures of $480{ }^{\circ} \mathrm{C}, 580{ }^{\circ} \mathrm{C}, 680{ }^{\circ} \mathrm{C}$ and $780{ }^{\circ} \mathrm{C}$ in triplicate in a furnace of a thermogravimetric analyzer (TA instruments Q500, UK) under nitrogen flow 
of $150 \mathrm{~cm}^{3} / \mathrm{min}$ at a ramping rate of $10{ }^{\circ} \mathrm{C}$ per minute from room temperature of about $28^{\circ} \mathrm{C}$. It was held at the respective carbonization temperatures for $2 \mathrm{~h}$ after which the resultant ACs were washed with hydrochloric acid. These were sequentially put in chromatographic columns and washed with warm distilled water to a $\mathrm{pH}$ of 6.9. The samples were then dried in an oven at $100^{\circ} \mathrm{C}$ for $12 \mathrm{~h}$ and kept in separate aluminum bottles for the subsequent analysis.

\section{Activated carbon characterization Yield and bulk density}

The resultant ACs were packed into a pre-weighed cylindrical crucible of mass $m_{1}$ and trimmed to the top to flash with the top most rim of the crucible. The filled crucible was weighed and the mass recorded as $m_{2}$. The sample mass, $m_{3}$ was obtained from; $m_{3}=m_{2}-m_{1}$. This was repeated thrice for every AC produced at a given carbonization temperature.

The inside diameter $(d)$ and the height $(h)$ of the crucible were measured using a vernier caliper and the volume calculated as per Menya et al. (2018):

$$
v=\pi(d / 2)^{2} h
$$

$$
\text { Bulk density, }\left(\mathrm{kg} / \mathrm{m}^{3}\right) \text { was calculated from }=\frac{m_{3}}{v} \times 1000 \text {. }
$$

The yield of the resulted activated carbon was expressed in percentage and calculated based on Eq. (3) by Omotosho and Amori (2016) as:

$$
\frac{\text { Weight of activated carbon }}{\text { Weight of raw peels }} \times 100 \% \text {. }
$$

\section{Specific surface area, pore size, distribution and volume}

The specific surface area and the pore volumes were determined from nitrogen isotherm at $77.3 \mathrm{~K}$ using the BET method and the micrometrics density functional theory (DFT) software for analysis. The BET surface area was calculated using the standard BET equation applied at a relative pressure range of 0.05 to 0.3 . Argon adsorption at $-186{ }^{\circ} \mathrm{C}$ was used to study the pore distribution from the adsorption isotherms. The adsorption data were analyzed using the DFT software, which enabled independent pore size determination.

\section{Functional surface group determination}

Fourier transform infrared spectroscopy, FTIR, was used to study the surface functional groups of raw cassava peels, pre-leached peels and the AC produced at $780{ }^{\circ} \mathrm{C}$ so that the chemical structure of the prepared AC could be determined. IR spectra were obtained with
FTIR spectrometer (Shimadzu, model FTIR-8300, Japan) using the transformation of 20 scans with a spectral resolution of $4 \mathrm{~cm}^{-1}$ by attenuated total reflectance method. FTIR spectra were collected in the mid-infrared region between 4500 and $500 \mathrm{~cm}^{-1}$. Spectra were acquired using air background correction.

\section{AC morphology}

The morphologies of the raw peels, pre-leached peels and the resultant powdered AC carbonized at 480, 580, 680 , and $780{ }^{\circ} \mathrm{C}$ were coated with gold using the sputtering technique and observed at a beam energy of $15 \mathrm{kV}$ on a FEI Quanta 600, USA, scanning electron microscope (SEM). For AC produced at $780{ }^{\circ} \mathrm{C}$, the formed briquette was analyzed both on the outer surface and on the crosssectional cut-away surface using the same SEM and a JEOL 2100F, USA, transmission electron microscope (TEM). The surface of the AC briquette was analyzed before and after washing with water. The milled AC from peels with and without pre-leaching was also analyzed to ascertain and compare the pore development. Analyzing the $780{ }^{\circ} \mathrm{C} \mathrm{AC}$ in briquette form was meant to ascertain the intercalation behavior of $\mathrm{K}$ above its boiling point.

\section{Results and discussion}

\section{Bulk density}

The bulk density for the resultant activated carbon was in the range $0.31-0.39 \mathrm{gcm}^{-3}$ (as shown in Fig. 1) which corroborates well with that reported by Parvathi et al. (2018), but lower than $0.410-0.415 \mathrm{gcm}^{-3}$ reported by Omotosho and Sangodoyin (2013). Bulk densities of AC yielded from cassava peels without pre-leaching are in the same ranges as those of AC in this study (Table 1) at carbonization temperature ranges of $480-680{ }^{\circ} \mathrm{C}$. At lower carbonization temperature ranges, intercalated

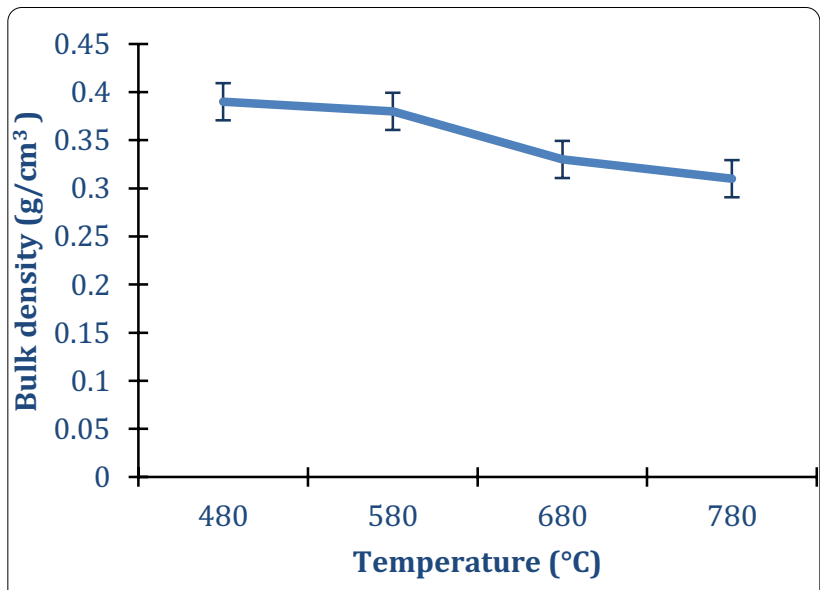

Fig. 1 AC bulk density variation with carbonization temperature 
Table 1 Comparison of the bulk densities of the AC produced with those from other studies

\begin{tabular}{llll}
\hline Precursor & AC bulk density $\left(\mathbf{g c m}^{-\mathbf{3}}\right)$ & Intended application & References \\
\hline Cassava peel & 0.415 & Effluent treatment & Omotosho and Sangodoyin (2013) \\
Cassava peel & $0.31-0.39$ & - & This study \\
Cassava peel & $0.36-0.48$ & Absorption of textile dyes & Parvathi et al. (2018) \\
Cassava peel & $0.407-0.413$ & Water decontamination & Omotosho and Amori (2016) \\
Hard wood & $0.55-0.88$ & - & Rodriguez-Reinoso (2002) \\
\hline
\end{tabular}

potassium remains in the carbon matrix. This compensates for the lost inorganic content due to pre-leaching and contributes to the carbon density. Besides, at such temperatures, some interstitial spaces may still be closed hence less release of volatile matter (Molina-Sabio and Rodríguez-Reinoso 2004). Bulk density is important when estimating the packing volume and the right grade for a new system design or modification of an existing system. Powdered carbons used for decolorization usually have a bulk density in the range $0.25-0.75 \mathrm{gcm}^{-3}$ while granular grades used in gas adsorption have a bulk density of around $0.40-0.50 \mathrm{gcm}^{-3}$ according to the ASTM D2854-70 standard.

The highest surface area $\mathrm{AC}$ produced at $780{ }^{\circ} \mathrm{C}$ had the lowest bulk density that could limit its application in some processes like adsorption and gas storage. The reduction in bulk density with increasing temperature could be due to the opening of the interstitial spaces (microspores) in the carbon residue coupled with release of a great quantity of the volatile matter at high carbonization temperature.

A trade-off of high porosity and surface area for lower bulk densities has been reported for chemically activated carbons (Casco et al. 2015; Wang and Kaskel 2012). Bulk density is also important in $\mathrm{AC}$ intended for a number of application in capacitors. Lower bulk densities imply reduced volumetric capacitance in super capacitors despite the much required high surface area and pore volumes such ACs might have (Wang and Kaskel 2012). The lower bulk density could also have a cost implication in absorption applications since more bed volumes could be needed per unit absorbate.

\section{Yield of activated carbon}

Results on the AC yield are presented in Fig. 2. The highest AC yield was $42 \%$ at $480{ }^{\circ} \mathrm{C}$. This is higher than $35 \%$ the maximum value reported by Sudaryanto et al. (2006) at 1:1 impregnation ratio, carbonization temperature of $450{ }^{\circ} \mathrm{C}$ and carbonization time of $1 \mathrm{~h}$ without pre-leaching. The yield reduced with increase in carbonization temperature, which is in agreement with other studies (Ekebafe et al. 2012). This is attributed to the carbon burn-off and the higher reaction rate of carbon and

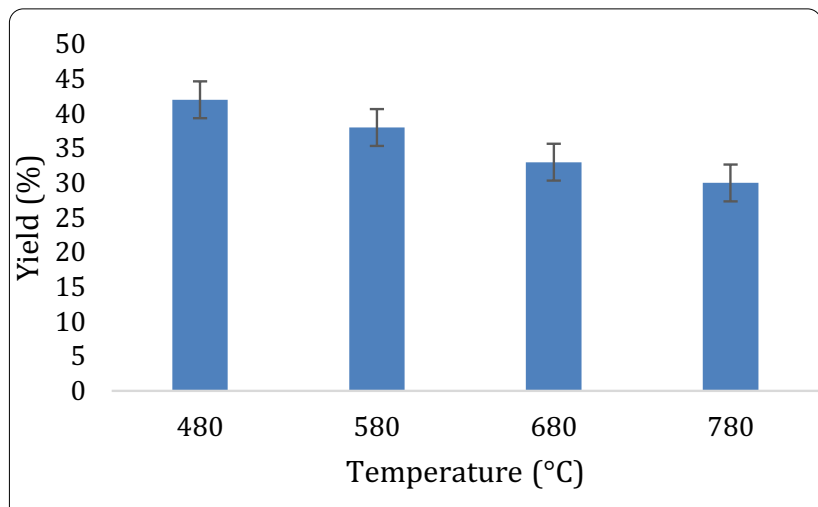

Fig. 2 Variation of AC yield with carbonizing temperature

$\mathrm{KOH}$ to release more volatile components with inherent improvement in the textural properties (Saka 2012). Other studies have reported reduction in AC yield due to increase in activation temperatures beyond certain limits (Kalderis et al. 2008; Sudaryanto et al. 2006; Yahya et al. 2015). For example, Sudaryanto et al. (2006) reported that the yield of the activated carbon at carbonization temperatures more than $650{ }^{\circ} \mathrm{C}$ were less than fixed carbon in the raw cassava peels. Other studies involving cassava peel AC without pre-leaching also report relatively lower yields in the range of $32.0-40.5 \%$ (Ndongo et al. 2020; Nwabanne and Igbokwe 2008; Omotosho and Amori 2016). The relatively higher yield of $A C$ at $780{ }^{\circ} \mathrm{C}$ could be attributed to the pre-leaching of the peels in this study. The raw peel ash content is less than $5 \% \mathrm{db}$, the typical ash percentage composition for AC precursors (Menya et al. 2018).

However, pre-leaching reduced the ash by $0.51 \%$, which could have contributed to an increase in char yield and subsequently upgraded to $\mathrm{AC}$ on activating. The small reduction in ash content yet high increment in $\mathrm{AC}$ yield renders the resultant $\mathrm{AC}$ diversely usable in a number of applications that require small amounts of ash like fuel cells and super capacitors (Xu et al. 2017) and humic acid adsorption (Daifullah et al. 2004). The high AC yield is partially attributed to the remarkably high lignin content 
in the NAROCAS 1 cassava variety (Kayiwa et al. 2021). High char yields have been reported from lignocellulosic precursors with relatively higher lignin compositions (Barskov et al. 2019; Sharypov et al. 2002). This is due to the high carbon content constituted in lignin (GonzálezGarcía 2018). The thermal treatment of hemicellulose and cellulose contained in the pre-leached cassava peel at temperatures above $250{ }^{\circ} \mathrm{C}$ contributed highly to the increase in the AC yield. This is because at such temperatures, there is an onset of elimination reactions along with crosslinking reactions leading to an increase in aromaticity.

\section{Pore characteristics (pore volume, pore distribution and BET surface area)}

The total pore volume $V_{\mathrm{t}}$ was in the range 0.432 to 0.756 $\mathrm{cm}^{3} \mathrm{~g}^{-1}$ and increased with increase in temperature as shown in Fig. 3. The resultant activated carbon exhibited a higher micropore volume $V_{\text {mic }}$ at $0.319-0.392 \mathrm{~cm}^{3} \mathrm{~g}^{-1}$ compared to mesopore volume $V_{\text {mes }}$ for temperatures $480-680{ }^{\circ} \mathrm{C}$. However, mesopore volume at $780{ }^{\circ} \mathrm{C}$ was remarkably higher than the micropore volume at 0.471 $\mathrm{cm}^{3} \mathrm{~g}^{-1}$ compared to $0.281 \mathrm{~cm}^{3} \mathrm{~g}^{-1}$. This could be due to the high lignin composition in the primary precursor. Lignocellulosic raw materials rich in lignin have been reported to yield highly mesoporous and macroporous activated carbon at temperatures higher than $650{ }^{\circ} \mathrm{C}$ (Gergova et al. 1993; Savova et al. 2001). The peels of NAROCAS 1 cassava variety were found to have relatively higher lignin compared with other predominant cassava varieties grown in Uganda (Kayiwa et al. 2021). The mesopores are important in facilitating access of the molecules to the microporosity, this being especially important in adsorption from solution processes. Other studies on deliberation of AC from cassava peels without pre-leaching reported lower pore volumes for the same or close carbonization temperature ranges. For example, Sudaryanto et al. (2006) reported total pore volumes of
0.421 to $0.519 \mathrm{~cm}^{3} \mathrm{~g}^{-1}$ for $\mathrm{AC}$ carbonized at $450-650{ }^{\circ} \mathrm{C}$. The difference could be due to the reduction in inorganic matter due to $\mathrm{NaOH}$ pre-leaching that enabled more spaces for volatile matter to escape during carbonization leading to more pore development. Micropores still dominate at these temperature ranges even for cassava peel $\mathrm{AC}$ without pre-leaching with relative increase in mesoporosity experienced with increasing temperature.

Decomposition of the lignin rich-derived char's carbonyl, hydroxyl, and carboxyl functional groups, at high activated temperatures in the ranges $600-800{ }^{\circ} \mathrm{C}$, produces volatile compounds $\left(\mathrm{H}_{2} \mathrm{O}\right.$ and $\left.\mathrm{CO}_{2}\right)$ and nonvolatile potassium carbonate $\left(\mathrm{K}_{2} \mathrm{CO}_{3}\right)$ (Lozano-Castelló et al. 2007). The in situ formation of $\mathrm{CO}_{2}$ and $\mathrm{H}_{2} \mathrm{O}$ during $\mathrm{KOH}$ activation process plays a role in the growth of pores. Yahya et al. (2015) reported that chemical activation at higher temperatures develops the porosity of lignocellulosic samples by removing the low-molecularweight volatile compounds from the matrix structure. The in situ physical process equations are detailed in a study by Wang and Kaskel (2012). Ramping the mixture of pre-leached Cassava peel and $\mathrm{KOH}$ to $780{ }^{\circ} \mathrm{C}$ and holding it at the same temperature for $2 \mathrm{~h}$ enabled the release of hydrogen and carbon monoxide gases. Moreover, the temperature is above the boiling point of metallic potassium $\left(760{ }^{\circ} \mathrm{C}\right)$. The metallic potassium gasified and this contributed to the high porosity of the resultant AC. Besides, the intercalated metallic potassium in the carbon matrix widened the lattice spaces between carbon atomic layers (Gratuito et al. 2008; Sudaryanto et al. 2006). These in situ synergistic occurrences do not only contribute to the ordered porous structure, but also increment in surface area due to increased pore volumes. Besides, the reactivity of carbon increases with temperature and this implies more release of free $\mathrm{K}$ whose intercalation creates more pores notwithstanding its potential occlusion of the micropores (Huang and Zhao 2016; Liu et al. 2015). However, on washing with hydrochloric acid

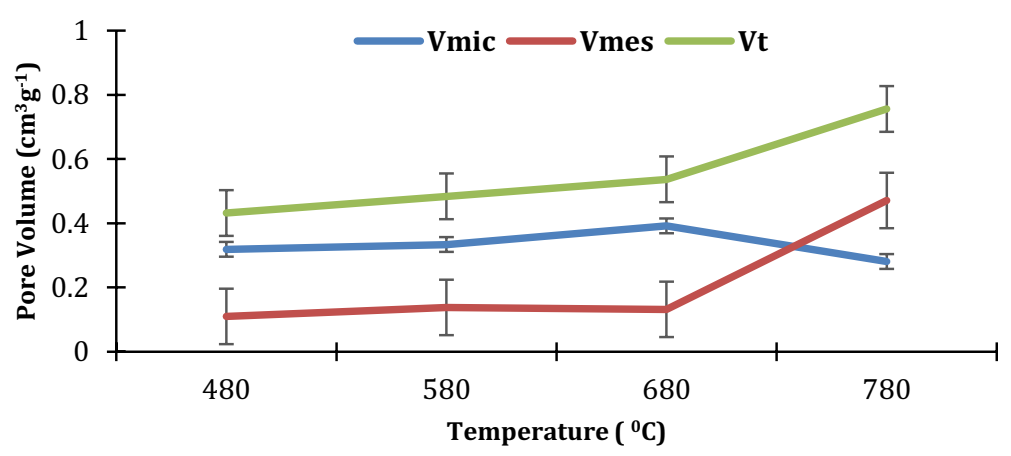

Fig. 3 Effect of carbonization temperature on the AC pore volume 
the blocked pores are freed enhancing the surface area as shown in Fig. 4.

The pore size distribution is shown in Fig. 5. At carbonization temperatures of $480-680^{\circ} \mathrm{C}$, the ACs contain micro and mesoporous structure while at $780{ }^{\circ} \mathrm{C}$ has significant mesoporous nature. This further confirms the role of the gasification of the intercalated potassium in widening the pores.

The surface area was remarkably highest at $1684 \mathrm{~m}^{2} \mathrm{~g}^{-1}$, a value higher than $1352 \mathrm{~m}^{2} \mathrm{~g}^{-1}$ reported by Ismanto et al. (2010) and $1567 \mathrm{~m}^{2} \mathrm{~g}^{-1}$ by Moreno-Piraján and Giraldo (2010). This is due to the pre-leaching that reduced ash forming elements in the peels and leaving relatively higher volatile mass composition. At high carbonization temperatures the volatile content gasifies leaving voids (pores) between carbon atom layers and hence increasing the surface area. In a study by Li et al. (2008) on the effects of carbonization temperature on the porosity development in coconut shell chars and activated carbon derived from coconut shell char, the pore volumes and surface area increased appreciably with increase in temperature from 400 to $1000{ }^{\circ} \mathrm{C}$. In the same study, surface area and pore volume for the samples at the

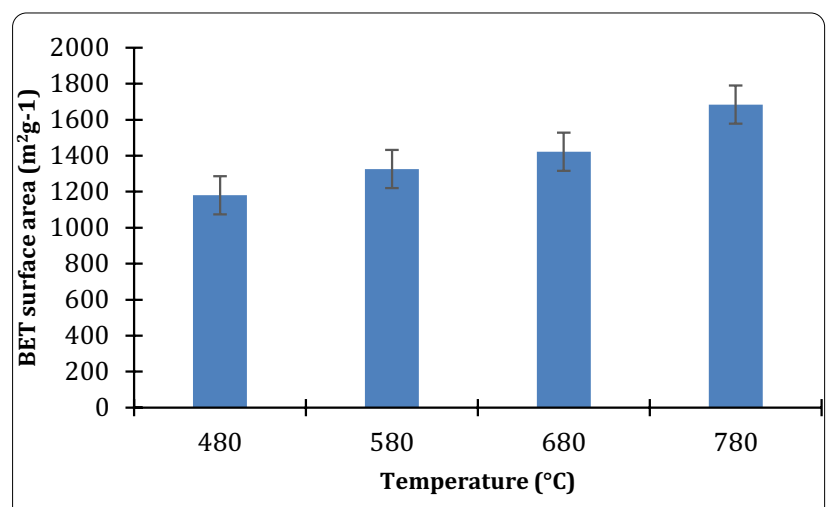

Fig. 4 Effect of carbonizing temperature on the AC surface area same carbonization temperature increased with activation time ( 0.5 to $2 \mathrm{~h}$ ). Moreover, $\mathrm{KOH}$ acts as a contraction inhibitor during carbonization. Cassava peel being lignocellulosic tends to contract more with increasing carbonization temperature. However, $\mathrm{KOH}$ deters such contraction, acting as a template for extra pore development (Molina-Sabio and Rodríguez-Reinoso 2004). With such a remarkable surface area, cassava peel AC could be leveraged for high-end applications like super capacitor electrodes. At $1684 \mathrm{~m}^{2} \mathrm{~g}^{-1}$, this surface area surpasses that of $1527-1634 \mathrm{~m}^{2} \mathrm{~g}^{-1}$ for AC made from peanut shell and rice husk for super capacitors by He et al. (2013).

\section{Active surface group analysis \\ Raw peels}

The active surface groups have the expected main heteroatoms of carbon, hydrogen and oxygen. There are several functional groups on the raw cassava peels' surface, namely hydroxyl, carboxyl, carboxylate and others as shown in Table 2. Similar groups were identified by other researchers (Mohd-Asharuddin, Othman, Mohd Zin, \& Tajarudin, 2017; Simate, Ndlovu, \& Seepe, 2015). In the same spectrum (Fig. 6a) at $1031 \mathrm{~cm}^{-1} \mathrm{C}-\mathrm{O}, \mathrm{C}=\mathrm{C}$, and $\mathrm{C}-\mathrm{C}-\mathrm{O}$ stretching can be attributed to $\mathrm{C}-\mathrm{O}-\mathrm{C}$ asymmetrical stretching of hemicellulose, cellulose, and lignin.

\section{Pre-leached peels}

When pre-leached, the active surface groups varied according to the FTIR spectra shown in Fig. 6b. A peak at wave number 1633 of the pre-leached cassava peel indicates a carboxylate stretch most likely from the reaction of $\mathrm{Na}^{+}$from $\mathrm{NaOH}$ with carboxyl groups in the peels. This interaction indicates potential for application as a chemisorption based adsorbent. With modifications such as Nitrogen doping, the same can be harnessed in extreme gas adsorption for example carbon dioxide capture (Liu et al. 2018). At 2913 and 2900 wave numbers, there is a distortion tendency for the $\mathrm{C}-\mathrm{H}$ bond. This

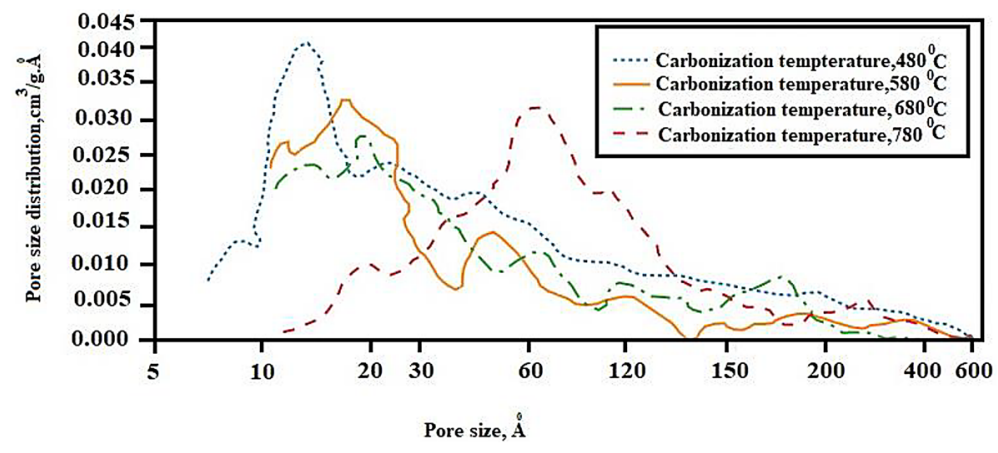

Fig. 5 Pore size distribution for ACs produced from pre-leached cassava peels 
Table 2 Identified surface groups from FTIR spectra compared with other studies

\begin{tabular}{|c|c|c|c|}
\hline Material under study & Wavelength $\left(\mathrm{cm}^{-1}\right)$ & Active surface group & References \\
\hline \multirow[t]{6}{*}{ Raw peel } & 3419 & Intermolecular OH & This study \\
\hline & 2915 & $\mathrm{C}-\mathrm{H}$ bond from aliphatic groups & \\
\hline & 2904 & $\mathrm{C}-\mathrm{H}$ bond from aliphatic groups & \\
\hline & 1751 & Carboxyl group stretching & \\
\hline & 1634 & Carboxylate groups & \\
\hline & 1031 & OH stretch (lignocellulosic precursors) & \\
\hline \multirow[t]{5}{*}{ Raw peel } & 500 & $-\mathrm{COOH}$ stretch & Simate et al. (2015) \\
\hline & $500-1000$ & OH stretch & \\
\hline & $1500-2000$ & $-\mathrm{C}=\mathrm{O}$ stretch & \\
\hline & $1000-1500$ & $-\mathrm{C}-\mathrm{O}$ stretch & \\
\hline & $3000-3500$ & $\mathrm{OH}$ stretch & \\
\hline \multirow[t]{3}{*}{ Raw peel } & $3700-3584$ & $\mathrm{O}-\mathrm{H}$ stretch & Idress et al. (2019) \\
\hline & $3550-3200$ & $\mathrm{O}-\mathrm{H}$ stretch & \\
\hline & 3500 & $\mathrm{~N}-\mathrm{H}$ stretch & \\
\hline \multirow[t]{6}{*}{ Pre-leached cassava peel } & 3412 & O-H groups of free hydroxyl groups & This study \\
\hline & 2913 & $\mathrm{C}-\mathrm{H}$ distortion & \\
\hline & 2900 & $\mathrm{C}-\mathrm{H}$ distortion & \\
\hline & 1755 & C-O bond of carboxyl groups & \\
\hline & 1633 & Carboxylate group stretch & \\
\hline & 1025 & C-O vibration & \\
\hline \multirow[t]{5}{*}{ AC from pre-leached cassava peel } & $3500-3600$ & $\mathrm{OH}$ group & This study \\
\hline & 2980 & Un saturated alkynes & \\
\hline & 1712 & Carbonyl group & \\
\hline & 1620 & Aromatic ring & \\
\hline & 1445 & Stretching $\mathrm{C}-\mathrm{C}$ bond & \\
\hline \multirow[t]{2}{*}{ AC from cassava peel } & 1147 & Aromatic $\mathrm{C}-\mathrm{H}$ of lignin & Belcaid et al. (2020) \\
\hline & 1575 & $\mathrm{C}=\mathrm{C}$ vibration of the aromatic nucleus & \\
\hline \multirow[t]{2}{*}{ AC from cassava peel } & 3841.83 & $\mathrm{OH}$ group & Astuti et al. (2020) \\
\hline & $1250-1170$ & O-C stretching & \\
\hline \multirow[t]{2}{*}{ Cassava rind carbon } & 1732 & $C=0$ stretch typical of aldehydes from hemicellulose & Beakou et al. (2017) \\
\hline & 1156 & C-O-C stretch typical of hemicellulose, cellulose, and lignin & \\
\hline \multirow[t]{3}{*}{ Cassava peel } & $3500-3200$ & $\begin{array}{l}\text { O-H group in polymeric compounds such as alcohols, phe- } \\
\text { nols and carboxylic acids presented in pectin, cellulose } \\
\text { and lignin on the cassava peels }\end{array}$ & Mohd-Asharuddin et al. (2017) \\
\hline & $1750-1680$ & Stretching vibration of $\mathrm{C}=\mathrm{O}$ bond of carboxyl groups & \\
\hline & $1300-1000$ & $\mathrm{C}-\mathrm{O}$ stretching of $\mathrm{COOH}$ & \\
\hline \multirow[t]{3}{*}{ Cassava peel } & 3412 & OH functional group & Rachman et al. (2017) \\
\hline & 1109 & $\mathrm{C}-\mathrm{O}$ vibration from secondary $\mathrm{OH}$ & \\
\hline & $3000-2750$ & Absorption band which is $\mathrm{C}-\mathrm{H} \mathrm{sp}^{3}$ & \\
\hline
\end{tabular}

could be due to the disruption of hemicellulose leading to elaboration of more lignin (Sun and Cheng 2002). The distortion in the $\mathrm{C}-\mathrm{H}$ bond indicates reduced crystallinity of the cellulose rich peels.

\section{Resultant $A C$}

The FTIR spectrum for the AC produced from preleached peels shows some band distortions as observed in Fig. 6c. Bands around $3500-3600 \mathrm{~cm}^{-1}$ are assigned to the stretching modes that are related to $\mathrm{OH}$ groups. The weak peak around $2980 \mathrm{~cm}^{-1}$ indicates the presence of the unsaturated alkynes $\mathrm{C}=\mathrm{C}$ stretching modes. This is further coupled with a vibration of $\mathrm{C}-\mathrm{H}$ bending mode around 625 to $875 \mathrm{~cm}^{-1}$. The band around $1620 \mathrm{~cm}^{-1}$ is related to the stretching vibrations of bonds of aromatic rings, those coupled with conjugated carbonyl groups on 


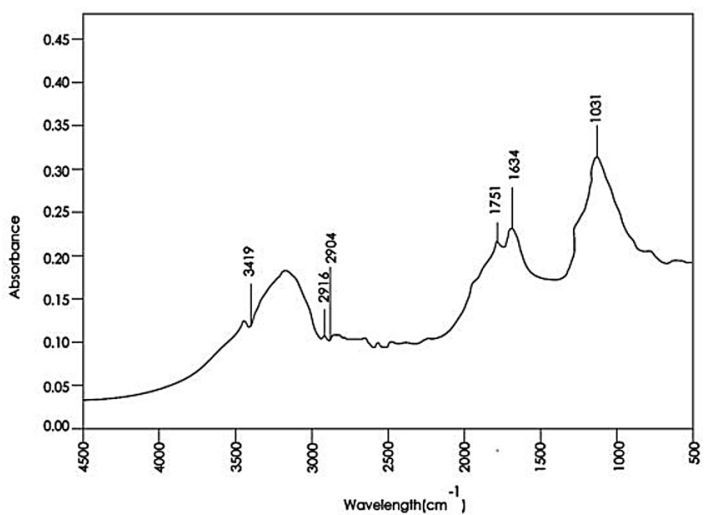

(a)

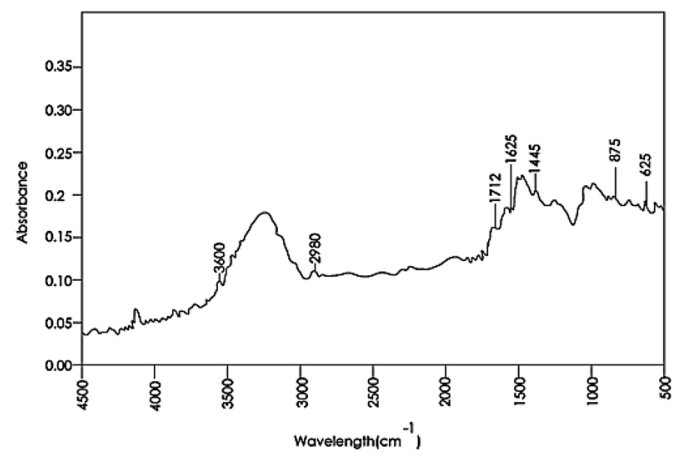

(c)

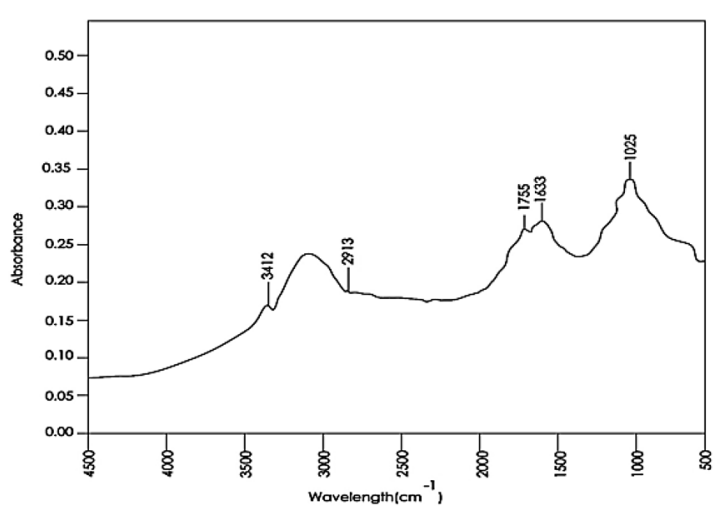

(b)

Fig. 6 FTIR spectra for: a raw cassava peel, $\mathbf{b}$ pre-treated peels and $\mathbf{c}$ the resultant AC

the surface (Belcaid et al. 2020). The $1712 \mathrm{~cm}^{-1}$ band corresponds to the stretching $\mathrm{C}=\mathrm{O}$ bond whereas the band at around $1445 \mathrm{~cm}^{-1}$ indicates vibratory stretching of the $\mathrm{C}-\mathrm{C}$ bond. The possible absorption bands for the $\mathrm{AC}$ were observed between 1425 and $1712 \mathrm{~cm}^{-1}$.

\section{Morphology}

SEM investigated the morphology of the raw and preleached cassava peels and the AC produced from preleached peels. Raw peels exhibited heterogeneity in their structure but no porosity with starch granules numerous on the surface (Fig. 7a). The pre-leached cassava peels showed a degraded structure (Fig. 7f) compared with the raw peels. This could be due to the formation carboxylates of $\mathrm{Na}$ with the carboxyl group in the raw peels which distorts the starch heterogeneity through depolymerizing (Uthumporn et al. 2012). This led to a less developed porous structure composed of a few enlarged pores and a degraded surface of starch granules.

The morphology of all ACs produced at temperatures 480, 580, and $680{ }^{\circ} \mathrm{C}$ from pre-leached peels showed densely fluffy porous structures that are indicative of smaller pores as shown in Fig. 7. These structures confirm the pore distribution shown in Fig. 5 with the highest curve peaks in the microporous ranges for these temperatures. The dominance of seemingly intrinsic micropores could be due to the crystallization of $\mathrm{K}$ into the intra-spaces limiting pore enlargement. This is due to the inability of $\mathrm{K}$ to gasify below $760{ }^{\circ} \mathrm{C}$. A slight visible variation in porosity is shown across the SEM images for the different carbonization temperatures with micropores enlarging more with increase in carbonization temperature. Increasing carbonization temperature from 480 to $680{ }^{\circ} \mathrm{C}$ effectively increases the release of volatile matter hence creating new pores and developing the existent. The structures of AC produced at or close temperature ranges from cassava peels without pre-leaching exhibit porous structures with intrinsic pores (Zdravkov et al. 2007).

The morphology of $\mathrm{AC}$ carbonized at $780{ }^{\circ} \mathrm{C}$ from cassava peels without pre-leaching had a highly porous structure with intraparticle pores that appear structurally 


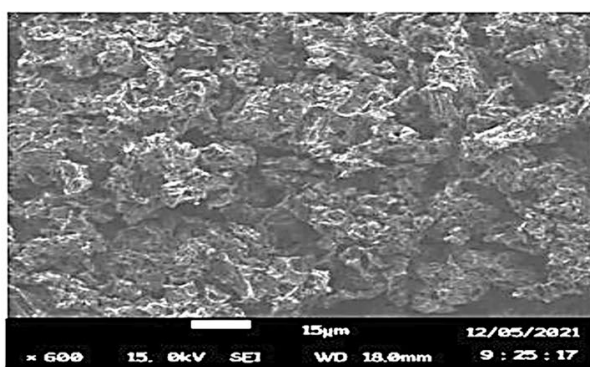

(a)

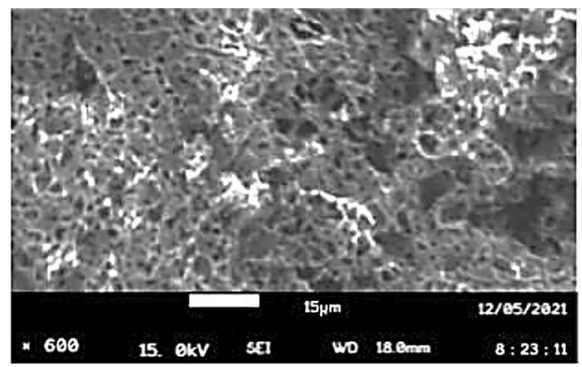

(c)

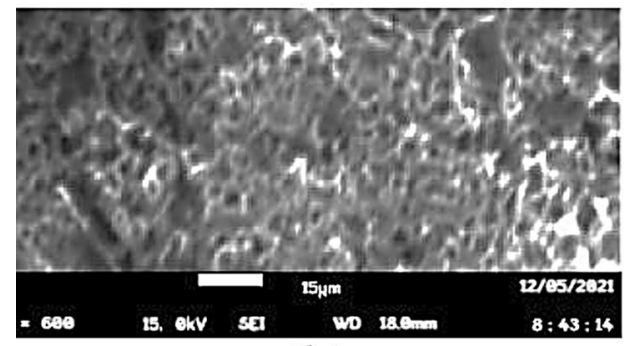

(b)

Fig. 7 SEM micrographs for pre-leached cassava peel AC at $\times 600$ resolution for carbonization temperatures: a $480^{\circ} \mathrm{C}, \mathbf{b} 580^{\circ} \mathrm{C}$, and $\mathbf{c} 680^{\circ} \mathrm{C}$

intrinsic as shown in Fig. 8f. This is due to the incorporated $\mathrm{K}$ into the interior of the carbon matrix, which inhibits the expected contraction with increasing temperature.

It is evident in Fig. 8 that $\mathrm{KOH}$ could have played a key role in pore formation by releasing free $\mathrm{K}$ from its reactions with carbon. The quasi-chemical bonding of carbon, oxygen and $\mathrm{K}(\mathrm{C}-\mathrm{O}-\mathrm{K})$ are therefore likely to have created new surface functionalities at temperatures above $700{ }^{\circ} \mathrm{C}$ hence the evidence of $\mathrm{K}$ species on the unwashed AC in Fig. 8c. The washed AC briquette in Fig. 8d shows that most of the free $\mathrm{K}$ surface species had been washed, whereas the cross-sectional view of the $\mathrm{AC}$ briquette in Fig. $8 \mathrm{~b}$ as per the TEM inset showed that $\mathrm{K}$ species had been intercalated into the carbon matrix. This further shows that the free $\mathrm{K}$ that could have crystallized with in the matrix sublimed due to the temperatures above its melting point leaving free pores as seen in Fig. 8e. The species intercalated in the AC matric are hence due to the quasi-chemical bonds most likely the $-\mathrm{O}-\mathrm{K}$ bond (Liu et al. 2015; Mopoung et al. 2015). The SEM image in Fig. 8e for the powdered $\mathrm{AC}$ showed a highly porous honeycomb structure with more extrinsic pores. This is indicative of an improved surface area (Omotosho and Amori 2016).

\section{Conclusions}

Pre-leaching cassava peels renders them more robust for preparation of high surface area activated carbon. This is enabled by the reduction in ash-forming agents leaving more volatile content that contributes to pore formation during carbonization. Pre-leaching also disrupts the hemicellulose hence liberating more lignin.

Cassava peel varieties with relatively higher lignin content are more likely to produce relatively more mesoporous $\mathrm{AC}$ at temperatures above $650{ }^{\circ} \mathrm{C}$ not withstanding lower yields and bulk densities of the resultant AC.

Carbonizing $\mathrm{KOH}$-activated cassava peels at temperatures above the melting point of potassium improves the surface area and pore volumes. Temperatures above $760{ }^{\circ} \mathrm{C}$ enable gasification of the intercalated metallic potassium contributing to formation of more pores. However, mesopores dominate such activated carbon relative to micropores due to the already widened interstitials by the intercalated potassium. This renders the resultant activated carbon applicable in adsorption of large molecules like pharmaceuticals. 


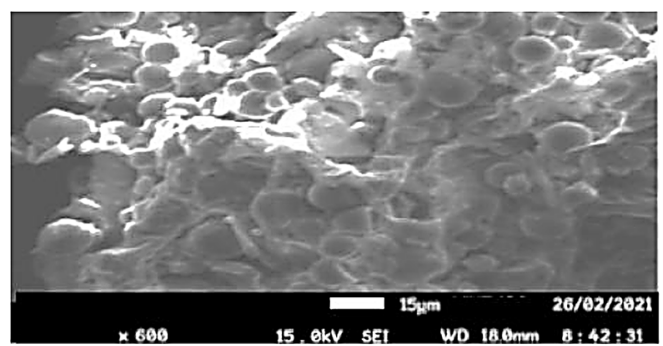

(a)

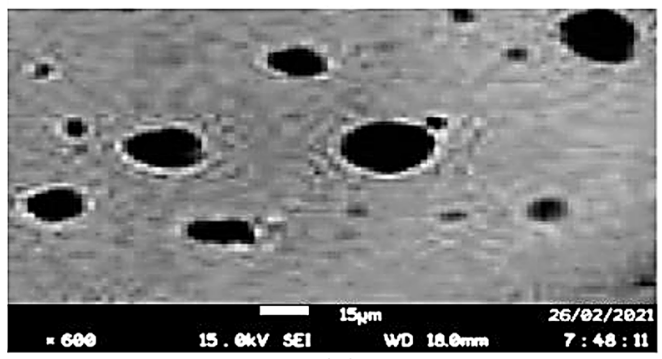

(c)

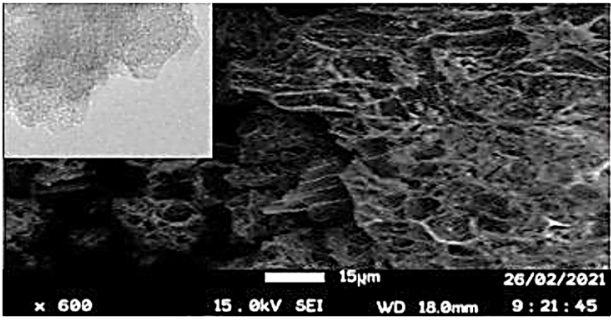

(e)

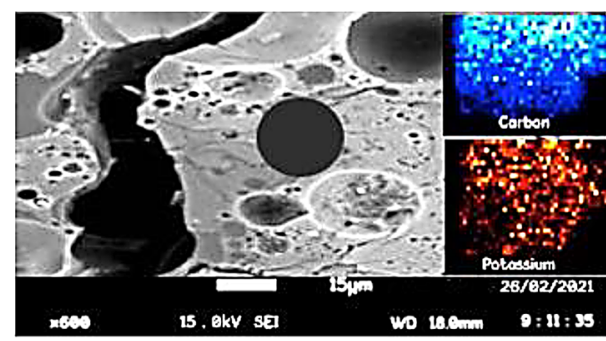

(b)

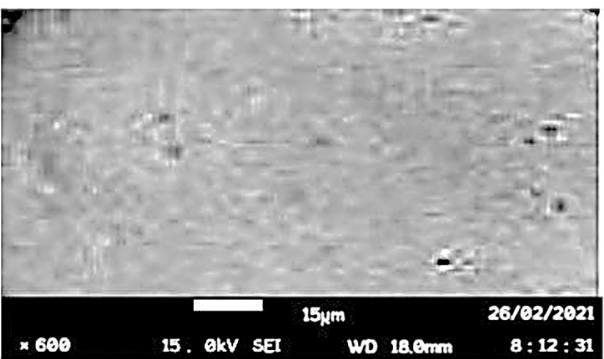

(d)

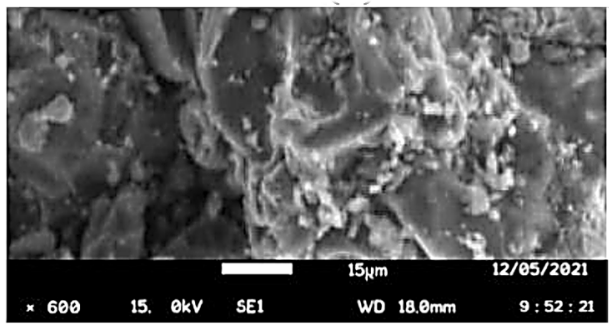

(f)

Fig. 8 SEM micrographs at $\times 600$ resolution and selected inset TEM images: a raw cassava peel; $\mathbf{b}$ cut-away surface for the washed AC briquette carbonized at $780^{\circ} \mathrm{C}$ and TEM AC image (inset) for carbon and potassium, c outer surface of the unwashed AC briquette carbonized at $780^{\circ} \mathrm{C} ; \mathbf{d}$ outer surface of the washed AC briquette; e powdered AC from pre-leached peels carbonized at $780^{\circ} \mathrm{C}$ and TEM AC image (inset) for activated carbon; $\mathbf{f}$ powdered $\mathrm{AC}$ carbonized at $780^{\circ} \mathrm{C}$ without pre-leaching

\section{Abbreviations}

AC: Activated carbon; FTIR: Fourier transform infrared; SEM: Scanning electron microscope.

\section{Acknowledgements}

The authors acknowledge the financial support provided by the African Centre of Excellence in Materials, Product Development \& Nanotechnology (MAPRONANO and the Government of Uganda through the Research and Innovation Fund-Makerere University.

\section{Authors' contributions}

RK-conceptualization, data collection, investigation and writing original draft. HK—supervision, writing — review and editing. ML—validation, resources and software. JBK — funding acquisition, methodology and project administration. All authors read and approved the final manuscript

\section{Funding}

African Centre of Excellence in Materials, Product Development \& Nanotechnology (MAPRONANO ACE).

Government of Uganda through the Research and Innovation Fund-Makerere University. Grant No. RIF1/CEDAT/007.
Availability of data and materials

The data and the materials are all available in this article as well as the supporting information.

\section{Declarations}

Ethics approval and consent to participate

Not applicable.

\section{Consent for publication}

Not applicable.

\section{Competing interests}

The authors report no declarations of interest.

Received: 7 April 2021 Accepted: 16 June 2021

Published online: 24 June 2021 


\section{References}

Adekunle A, Orsat V, Raghavan V (2016) Lignocellulosic bioethanol: a review and design conceptualization study of production from cassava peels. Renew Sustain Energy Rev 64:518-530. https://doi.org/10.1016/j.rser. 2016.06 .064

Alves TC, Cabrera-Codony A, Barceló D, Rodriguez-Mozaz S, Pinheiro A, Gonzalez-Olmos R (2018) Influencing factors on the removal of pharmaceuticals from water with micro-grain activated carbon. Water Res 144:402-412. https://doi.org/10.1016/J.WATRES.2018.07.037

Astuti W, Hidayah M, Fitriana L, Mahardhika MA, Irchamsyah EF (2020) Preparation of activated carbon from cassava peel by microwave-induced H3PO4 activation for naphthol blue-black removal. In: AIP conference proceedings, 2243(June). https://doi.org/10.1063/5.0001464

Barskov S, Zappi M, Buchireddy P, Dufreche S, Guillory J, Gang D et al (2019) Torrefaction of biomass: a review of production methods for biocoal from cultured and waste lignocellulosic feedstocks. Renew Energy 142:624642. https://doi.org/10.1016/j.renene.2019.04.068

Beakou BH, El Hassani K, Houssaini MA, Belbahloul M, Oukani E, Anouar A (2017) Novel activated carbon from Manihot esculenta Crantz for removal of methylene blue. Sustain Environ Res 27(5):215-222. https://doi.org/10. 1016/J.SERJ.2017.06.003

Belcaid A, Beakou BH, El Hassani K, Bouhsina S, Anouar A (2020) Efficient removal of $\mathrm{Cr}(\mathrm{VI})$ and $\mathrm{Co}(\mathrm{II})$ from aqueous solution by activated carbon from Manihot esculenta Crantz agricultural bio-waste. Water Sci Technol. https://doi.org/10.2166/wst.2020.585

Bhatnagar A, Sillanpää M, Witek-Krowiak A (2015) Agricultural waste peels as versatile biomass for water purification - a review. Chem Eng J 270:244-271. https://doi.org/10.1016/j.cej.2015.01.135

Casco ME, Martínez-Escandell M, Kaneko K, Silvestre-Albero J, Rodríguez-Reinoso F (2015) Very high methane uptake on activated carbons prepared from mesophase pitch: a compromise between microporosity and bulk density. Carbon 93:11-21. https://doi.org/10.1016/j.carbon.2015.05.029

Daifullah AAM, Girgis BS, Gad HMH (2004) A study of the factors affecting the removal of humic acid by activated carbon prepared from biomass material. Colloids Surf A 235(1-3):1-10. https://doi.org/10.1016/j.colsurfa. 2003.12.020

Daud WMAW, Ali WSW (2004) Comparison on pore development of activated carbon produced from palm shell and coconut shell. Biores Technol 93(1):63-69. https://doi.org/10.1016/j.biortech.2003.09.015

Ekebafe LO, Imanah JE, Okieimen FE (2012) Effect of carbonization on the processing characteristics of rubber seed shell. Arab J Chem 10:S174-S178. https://doi.org/10.1016/j.arabjc.2012.07.018

Gani A, Naruse I (2007) Effect of cellulose and lignin content on pyrolysis and combustion characteristics for several types of biomass. Renew Energy 32(4):649-661. https://doi.org/10.1016/j.renene.2006.02.017

Gergova K, Petrov N, Minkova V (1993) A comparison of adsorption characteristics of various activated carbons. J Chem Technol Biotechnol 56(1):77-82. https://doi.org/10.1002/jctb.280560114

González-García P (2018) Activated carbon from lignocellulosics precursors: a review of the synthesis methods, characterization techniques and applications. Renew Sustain Energy Rev 82:1393-1414. https://doi.org/10. 1016/j.rser.2017.04.117

Gratuito MKB, Panyathanmaporn T, Chumnanklang RA, Sirinuntawittaya N, Dutta A (2008) Production of activated carbon from coconut shell: optimization using response surface methodology. Biores Technol 99(11):4887-4895. https://doi.org/10.1016/j.biortech.2007.09.042

He X, Ling P, Qiu J, Yu M, Zhang X, Yu C, Zheng M (2013) Efficient preparation of biomass-based mesoporous carbons for supercapacitors with both high energy density and high power density. J Power Sources 240:109-113. https://doi.org/10.1016/j.jpowsour.2013.03.174

Huang Y, Zhao G (2016) Preparation and characterization of activated carbon fibers from liquefied wood by $\mathrm{KOH}$ activation. Holzforschung 70(3):195202. https://doi.org/10.1515/hf-2015-0051

Ibeh PO, García-Mateos FJ, Rosas JM, Rodríguez-Mirasol J, Cordero T (2019) Activated carbon monoliths from lignocellulosic biomass waste for electrochemical applications. J Taiwan Inst Chem Eng 97:480-488. https://doi. org/10.1016/j.jtice.2019.02.019

Idress M, Shahril MA, Zuraidin AS, Jasamai M (2019) Experimental investigation of methane hydrate induction time in the presence of cassava peel as a hydrate inhibitor. Energies 12(12):1-11. https://doi.org/10.3390/en121 22314
Ismanto AE, Wang S, Soetaredjo FE, Ismadji S (2010) Preparation of capacitor's electrode from cassava peel waste. Biores Technol 101(10):3534-3540. https://doi.org/10.1016/j.biortech.2009.12.123

Kalderis D, Bethanis S, Paraskeva P, Diamadopoulos E (2008) Production of activated carbon from bagasse and rice husk by a single-stage chemical activation method at low retention times. Biores Technol 99(15):68096816. https://doi.org/10.1016/j.biortech.2008.01.041

Kayiwa R, Kasedde H, Lubwama M, Kirabira JB (2021) Characterization and preleaching effect on the peels of predominant cassava varieties in Uganda for production of activated carbon. Curr Res Green Sustain Chem. https:// doi.org/10.1016/j.crgsc.2021.100083

Kwiatkowski M, Broniek E (2017) An analysis of the porous structure of activated carbons obtained from hazelnut shells by various physical and chemical methods of activation. Colloids Surf A 529:443-453. https://doi. org/10.1016/j.colsurfa.2017.06.028

Laine J, Yunes S (1992) Effect of the preparation method on the pore size distribution of activated carbon from coconut shell. Carbon 30(4):601-604. https://doi.org/10.1016/0008-6223(92)90178-Y

Li W, Yang K, Peng J, Zhang L, Guo S, Xia H (2008) Effects of carbonization temperatures on characteristics of porosity in coconut shell chars and activated carbons derived from carbonized coconut shell chars. Ind Crops Prod 28(2):190-198. https://doi.org/10.1016/j.indcrop.2008.02.012

Liu J, Sun N, Sun C, Liu H, Snape C, Li K et al (2015) Spherical potassium intercalated activated carbon beads for pulverised fuel $\mathrm{CO} 2$ post-combustion capture. Carbon 94:243-255. https://doi.org/10.1016/j.carbon.2015.06. 036

Liu J, Liu X, Sun Y, Sun C, Liu H, Stevens LA et al (2018) High density and super ultra-microporous-activated carbon macrospheres with high volumetric capacity for $\mathrm{CO}_{2}$ capture. Adv Sustain Syst 2(2):1700115. https://doi.org/ 10.1002/adsu.201700115

Lozano-Castelló D, Calo JM, Cazorla-Amorós D, Linares-Solano A (2007) Carbon activation with $\mathrm{KOH}$ as explored by temperature programmed techniques, and the effects of hydrogen. Carbon 45(13):2529-2536. https:// doi.org/10.1016/j.carbon.2007.08.021

Lu Y, Zhang S, Yin J, Bai C, Zhang J, Li Y et al (2017) Mesoporous activated carbon materials with ultrahigh mesopore volume and effective specific surface area for high performance supercapacitors. Carbon 124:64-71. https://doi.org/10.1016/j.carbon.2017.08.044

Menya E, Olupot PW, Storz H, Lubwama M, Kiros Y (2018) Characterization and alkaline pretreatment of rice husk varieties in Uganda for potential utilization as precursors in the production of activated carbon and other value-added products. Waste Manage 81:104-116. https://doi.org/10. 1016/j.wasman.2018.09.050

Mohd-Asharuddin S, Othman N, Mohd Zin NS, Tajarudin HA (2017) A chemical and morphological study of cassava peel: a potential waste as coagulant aid. In: MATEC web of conferences, vol 103. https://doi.org/10.1051/ matecconf/201710306012

Molina-Sabio M, Rodríguez-Reinoso F (2004) Role of chemical activation in the development of carbon porosity. Colloids Surf A 241(1-3):15-25. https:// doi.org/10.1016/j.colsurfa.2004.04.007

Mopoung S, Moonsri P, Palas W, Khumpai S (2015) Characterization and properties of activated carbon prepared from tamarind seeds by $\mathrm{KOH}$ activation for Fe(III) adsorption from aqueous solution. Sci World J. https://doi. org/10.1155/2015/415961

Moreno-Piraján JC, Giraldo L (2010) Study of activated carbons by pyrolysis of cassava peel in the presence of chloride zinc. J Anal Appl Pyrol 87(2):288-290. https://doi.org/10.1016/j.jaap.2009.12.003

Mukiibi DR, Alicai T, Kawuki R, Okao-Okuja G, Tairo F, Sseruwagi P et al (2019) Resistance of advanced cassava breeding clones to infection by major viruses in Uganda. Crop Prot 115:104-112. https://doi.org/10.1016/j. cropro.2018.09.015

Ndongo GK, Nsami NJ, Mbadcam KJ (2020) Ferromagnetic activated carbon from cassava (Manihot dulcis) peels activated by iron(III) chloride: synthesis and characterization. BioResources 15(2):2133-2146. https://doi.org/ 10.15376/biores.15.2.2133-2146

Nwabanne JT, Igbokwe PK (2008) Kinetics and equilibrium modeling of nickel adsorption by cassava peel. J Eng Appl Sci 3(11):829-834

Okudoh V, Trois C, Workneh T, Schmidt S (2014) The potential of cassava biomass and applicable technologies for sustainable biogas production in South Africa: a review. Renew Sustain Energy Rev 39:1035-1052. https:// doi.org/10.1016/j.rser.2014.07.142 
Omotosho O, Amori A (2016) Effect of zinc chloride activation on physicochemical characteristics of cassava peel and waste bamboo activated carbon. Int J Chem Mol Eng 6:815-820

Omotosho OA, Sangodoyin AY (2013) Production and utilization of cassava peel activated carbon in treatment of effluent from cassava processing industry. Water Pract Technol 8(2):215-224. https://doi.org/10.2166/wpt 2013.023

Parvathi C, Shoba US, Prakash C, Sivamani S (2018) Manihot esculenta peel powder: effective adsorbent for removal of various textile dyes from aqueous solutions. J Test Eval 46(6):20170160. https://doi.org/10.1520/ jte20170160

Rachman RA, Tri U, Martia I, Pambudi AB, Jovita S, Kurniawan F (2017) Cassava peel biosorbent (manihot utilissima) for removal chromium (Vi) with microbial fuel cell system of combination techniques. Proc Int Conf Green Technol 8(1):235-239

Rodriguez-Reinoso F (2002) Carbons. In: Schuth F, Sing KS, Weitkamp J (eds) Handbbok of porous solids, 69469, vol 3. Wiley-VCH Verlag GmbH, Weinheim, pp 1766-1827

Rodríguez-Reinoso F (2006) Porous carbons in gas separation and storage. In: Loureiro JM, Kartel MT (eds) Combined and hybrid adsorbents. Springer, Dordrecht, pp 133-144. https://doi.org/10.1007/1-4020-5172-7_15

Saka C (2012) BET, TG-DTG, FT-IR, SEM, iodine number analysis and preparation of activated carbon from acorn shell by chemical activation with $\mathrm{ZnCl}$ 2. J Anal Appl Pyrol 95:21-24. https://doi.org/10.1016/j.jaap.2011.12.020

Salahudeen N, Ajinomoh C, Omaga S, Akpaka C (2014) Production of activated carbon from cassava. J Appl Phytotechnol Environ Sanit 3(2):75-80

Santos VLF, Ferreira MA, Siqueira MCB, Melo TTB, Silva JL, Andrade IB et al (2015) Rumen parameters of sheep fed cassava peel as a replacement for corn. Small Rumin Res 133:88-92. https://doi.org/10.1016/j.smallrumres. 2015.09.010

Savova D, Apak E, Ekinci E, Yardim F, Petrov N, Budinova T et al (2001) Biomass conversion to carbon adsorbents and gas. Biomass Bioenerg 21(2):133142. https://doi.org/10.1016/S0961-9534(01)00027-7

Sharypov VI, Marin N, Beregovtsova NG, Baryshnikov SV, Kuznetsov BN, Cebolla VL, Weber JV (2002) Co-pyrolysis of wood biomass and synthetic polymer mixtures. Part I: influence of experimental conditions on the evolution of solids, liquids and gases. J Anal Appl Pyrol 64(1):15-28. https://doi.org/10. 1016/S0165-2370(01)00167-X
Shirima RR, Legg JP, Maeda DG, Tumwegamire S, Mkamilo G, Mtunda K et al (2020) Genotype by environment cultivar evaluation for cassava brown streak disease resistance in Tanzania. Virus Res 286:198017. https://doi. org/10.1016/j.virusres.2020.198017

Simate GS, Ndlovu S, Seepe L (2015) Removal of heavy metals using cassava peel waste biomass in a multi-stage countercurrent batch operation. J Southern Afr Inst Min Metal 115(12):1137-1141. https://doi.org/10.17159/ 2411-9717/2015/v115n12a1

Sudaryanto Y, Hartono SB, Irawaty W, Hindarso H, Ismadji S (2006) High surface area activated carbon prepared from cassava peel by chemical activation. Biores Technol 97(5):734-739. https://doi.org/10.1016/j.biortech.2005.04. 029

Sun Y, Cheng J (2002) Hydrolysis of lignocellulosic materials for ethanol production: a review. Biores Technol 83(1):1-11. https://doi.org/10.1016/ S0960-8524(01)00212-7

Uthumporn U, Shariffa YN, Fazilah A, Karim AA (2012) Effects of $\mathrm{NaOH}$ treatment of cereal starch granules on the extent of granular starch hydrolysis. Colloid Polym Sci 290(15):1481-1491. https://doi.org/10.1007/ s00396-012-2674-2

Wang J, Kaskel S (2012) KOH activation of carbon-based materials for energy storage. J Mater Chem 22(45):23710-23725. https://doi.org/10.1039/ c2jm34066f

Xu X, Zhao Y, Sima J, Zhao L, Mašek O, Cao X (2017) Indispensable role of biochar-inherent mineral constituents in its environmental applications: a review. Biores Technol 241:887-899. https://doi.org/10.1016/j.biortech. 2017.06.023

Yahya MA, Al-Qodah Z, Ngah CWZ (2015) Agricultural bio-waste materials as potential sustainable precursors used for activated carbon production: a review. Renew Sustain Energy Rev 46:218-235. https://doi.org/10.1016/j. rser.2015.02.051

Zdravkov BD, Čermák JJ, Šefara M, Janků J (2007) Pore classification in the characterization of porous materials: a perspective. Cent Eur J Chem 5(2):385-395. https://doi.org/10.2478/s11532-007-0017-9

\section{Publisher's Note}

Springer Nature remains neutral with regard to jurisdictional claims in published maps and institutional affiliations.

\section{Submit your manuscript to a SpringerOpen ${ }^{\circ}$ journal and benefit from:}

- Convenient online submission

- Rigorous peer review

- Open access: articles freely available online

- High visibility within the field

- Retaining the copyright to your article

Submit your next manuscript at $\boldsymbol{\nabla}$ springeropen.com 